\title{
Polacy i Niemcy w geopolitycznej przestrzeni XX w. ${ }^{1}$
}

Problem zawarty w tytule pracy nie jest wyłącznie $\mathrm{z}$ gatunku akademickich odnosi się do geopolitycznego obszaru polityki polskiej w XX w. O ile nie budzi wątpliwości okres do 1918 r. (Wielka Wojna i okres ją poprzedzający) oraz - chociaż w mniejszym stopniu - lata 1939-1945 (II wojna światowa), o tyle przedmiotem sporu i analiz jest okres istnienia systemu totalitarnego po 1945 r. oraz dekompozycji komunizmu w europejskich krajach sowieckich i postsowieckich po $1990 \mathrm{r}$.

Wśród niezależnych publicystów i historyków bowiem pojawiły się konstatacje, iż przez większość minionego stulecia polityczny status narodu i państwa to właściwie okupacja, a w pewnych okresach nawet „coś gorszego" niż stan niewoli, braku suwerenności i podmiotowości. Polityczny dyskurs wokół politycznej przestrzeni polskości stanowi przedmiot niniejszej pracy. Autor powyższej diagnozy: Józef Mackiewicz, pisarz, publicysta, intelektualista - to postać wybitna. Do jego przenikliwych myśli i diagnoz będziemy jeszcze wracać ${ }^{2}$. Nader interesująca jest refleksja historyczna oraz uwagi Oskara Haleckiego, znakomitego polskiego badacza dziejów, pracującego po wrześniu 1939 r. na emigracji, opublikowane w 1945 r., na temat rozbiorów Rzeczypospolitej. Do trzech pierwszych rozbiorów $(1772,1793,1795)$ doliczył on układ niemiecko-sowiecki z 28 września 1939 r. jako piąty rozbiór Polski, gdyż wcześniej jeszcze los państwa rozstrzygnięty został na kongresie wiedeńskim w 1815 r. Wówczas bowiem, podobnie jak w 1795 r., nastąpił całkowity rozbiór kraju. Ponadto zasadnie zauważył, iż nie sposób nazwać

\footnotetext{
${ }^{1}$ Obszerniej na ten temat por.: G. Łukomski, Polityczna przestrzeń polskości w XX w. Bezpieczeństwo polityczne Rzeczypospolitej z perspektywy racji stanu, Poznań-Londyn 2013.

2 J. Mackiewicz, Okupacja - czy coś gorszego? O Ninie Karsov kontrrewolucyjnym piórem, „Wiadomości" (Londyn) 1970, nr 12/13.
} 
Polską sztucznie wykrojonych niesuwerennych bytów politycznych, takich jak „Królestwo Polskie” czy „Wolne Miasto Kraków”. Wszystkie osiemnastowieczne traktaty rozbiorowe, nawet jeśli dotyczyły jedynie części obszaru Rzeczypospolitej, były porozumieniami zawartymi pomiędzy obcymi państwami, bez udziału "ofiary". Następnie narzucano je władzom Polski w postaci bezwarunkowej kapitulacji.

Decyzje konferencji krymskiej z 11 lutego 1945 r. dotyczące Polski były jak słusznie twierdzi Halecki - szóstym rozbiorem, ponieważ, podobnie jak niegdyś w latach 1795, 1815 i 1939, rozdysponowano całość terytorium Polski „W sposób szczególnie nawiązujący do kongresu wiedeńskiego i metodą charakterystyczną dla pięciu poprzednich rozbiorów". Pośród szeregu różnic między poprzednimi a decyzjami z $1945 \mathrm{r}$. najbardziej spektakularna dotyczyła faktu, iż tym razem Polska nie walczyła po przegranej stronie przeciwko mocarstwom rozbiorowym. „[...] Polska nie tylko nie była satelitą pokonanego wroga, ale jako pierwsza oparła się jego agresji i nigdy nie przestała walczyć po stronie Narodów Zjednoczonych, które - nie mogąc jej pomóc w momencie piątego rozbioru w 1939 r. - teraz w 1945 r., u progu wspólnego zwycięstwa przystąpiły do kolejnego rozbioru tego wiernego sojusznika $[\ldots]^{\prime \prime}$. Największa jednak różnica dotyczy mocarstw rozbiorowych. We wszystkich pięciu poprzednich przypadkach Polska została podzielona między Niemcy i Rosję, z tą jedynie różnicą, iż w latach 1772, 1795 i 1815 stronę niemiecką reprezentowały dwa państwa, Prusy i Austria, w 1793 r. same Prusy, a w 1939 r. zjednoczone Niemcy. Rosja tymczasem zastąpiona została przez Związek Sowiecki, co stanowi jedynie różnicę formalną. W przypadku szóstego rozbioru oba mocarstwa anglosaskie nie tylko nie uczestniczyły fizycznie w rozbiorze, lecz nie odniosły korzyści z przeprowadzonej transakcji. Szósty rozbiór miał zatem osobliwy charakter, dokonany został wewnątrz imperium sowieckiego. „[...] Można zasadnie stwierdzić, że Polska została podzielona pomiędzy obywatelami Rosji Sowieckiej: p[anem] Stalinem a p[anem] Bierutem. Jakkolwiek szokujące $\mathrm{w}$ tych okolicznościach może być polskie pochodzenie jednego $\mathrm{z}$ nich, to jednak $\mathrm{w}$ istocie jest równie bez znaczenia co gruzińskie pochodzenie drugiego $[\ldots]^{\prime 4}$.

Konkluzja narzuca się sama. Polacy nie zostali wyzwoleni. Sowieckie zwycięstwa nad Niemcami ,[...] byłyby wspaniałym wkładem w wyzwolenie Polski, dopełniającym działania zachodnich sojuszników i samych Polaków, gdyby po wkroczeniu na terytorium polskie, w drodze na Berlin, Rosja sowiecka przyjęła oferowaną jej na polecenie rządu polskiego współpracę z Armia Krajową, gdyby administracja na wyzwolonych ziemiach została przekazana Polskiemu Państwu Podziemnemu, istniejącemu nawet pod

${ }^{3}$ O. Halecki, Szósty rozbiór Polski, w: J. Cisek, Oskar Halecki, Historyk. Szermierz wolności, Warszawa 2009, s. 218. Tekst opublikowany po raz pierwszy w języku angielskim: The Sixth Partition of Poland, „The Review of Politics” 1945, t. 7, nr 2, s. 142-155.

${ }^{4}$ Tamże, s. 219. 
niemiecką okupacją, i gdyby pozwolono na powrót do Polski prawowitemu rządowi cieszącemu się stałą lojalnością ruchu oporu, zarówno cywilnego jak i wojskowego. Nastąpiło coś absolutnie odwrotnego, zatem w sojuszniczej Polsce, podobnie jak w neutralnych państwach bałtyckich, wypędzenie Niemców nie było oczekiwanym wyzwoleniem, ale jedynie zamianą jednej obcej okupacji na drugą $[\ldots]^{\prime \prime}$.

Bez wątpienia problem skłania do szerszej refleksji historycznej i pytań związanych z wielowiekowym trudnym sąsiedztwem polsko-niemieckim, wzajemną akulturacją, mającą swoje pozytywne i negatywne skutki, splataniem się w naszych dziejach wielkiej polityki i mikrohistorii, ludzkich losów wpisanych w dzieje obu narodów. Obfitowały owe dzieje w wydarzenia trudne i tragiczne, a apogeum tych ostatnich nastąpiło właśnie $\mathrm{w}$ wieku $\mathrm{XX}$, okresie dwóch wojen światowych, masowych zbrodni niemieckich na niespotykaną dotąd skalę. W przeszłości relacje polsko-niemieckie kreowali nade wszystko intelektualiści i politycy i oni narzucali je społeczeństwom. Dominowały więc takie nadrzędne pojęcia, jak: racja stanu, geopolityka, interes narodowy etc. Spójrzmy na problem z takiej właśnie perspektywy, bez emocji, w sposób naukowy, sine ira et studio, bez gniewu i zawziętości.

Polską racją stanu w XX w. powojenna historiografia krajowa zajmowała się niezbyt chętnie, $\mathrm{w}$ przeciwieństwie do polskich autorów piszących poza granicami kraju. Powody tego faktu są oczywiste - przede wszystkim natury politycznej. $\mathrm{W}$ niesuwerennym, totalitarnym państwie komunistycznym trudno było podejmować problem, zwłaszcza w realiach politycznych i perspektywie wieku XX. Liczył się bowiem wyłącznie interes i rozprzestrzenianie ideologii oraz systemu, natomiast interes i dobro państwa, a więc także narodu, stanowiły jedynie element gry propagandowej. Nie było zatem o czym mówić, by nie powiedzieć prawdy. Także w okresie drugiej transformacji ustrojowej (pierwsza miała miejsce w latach 1944-1948), po 1990 r., problem nie wzbudzał początkowo nadmiernego zainteresowania badaczy ${ }^{6}$.

Z kolei geopolityka także była swoistym tabu politycznym w sowieckim kraju nad Wisłą, czyli „Polskiej Rzeczypospolitej Ludowej” (PRL) po 1945 r. Sformułowana na przełomie XIX i XX w. doktryna polityczna głosiła, iż rozwój społeczno-polityczny państw i narodów zdeterminowany jest ich geograficznym położeniem. Jej prekursorami byli Niemcy, a zatem niemiecki obszar geopolityczny analizowano szczegółowo i - przyznać należy - z niemałym zapałem. Początki dał Friedrich Ratzel (1844-1904), niemiecki geograf, twór-

\footnotetext{
5 Tamże, s. 225. Podkreślenia w oryginale.

${ }^{6}$ Racja stanu (z fr. raison d'État) - nadrzędny interes państwowy, wyższość interesu państwa nad innymi interesami i normami, wspólny dla większości obywateli i organizacji działających w państwie lub poza jego granicami, ale na jego rzecz. Za twórcę nowożytnej koncepcji racji stanu uważany jest Niccolo Machiavelli, natomiast pierwsze użycie terminu „racja stanu” przypisuje się arcybiskupowi Giovanniemu della Casa. Por.: A. Rzegocki, Racja stanu a polska tradycja myślenia o polityce, Kraków 2008, s. 35-39.
} 
ca podstaw geopolityki niemieckiej, który definiował państwo jako „organizm przypisany do ziemi”, uznając przestrzeń za jego najistotniejszą część. Dążenie do jej powiększania stanowiło zatem zjawisko naturalne („,prawo rosnących przestrzeni"). Za pierwszą naukową pracę geopolityczną uznać należy studium Leopolda von Rankego, jednego z twórców nowoczesnej historiografii, o relacjach sił wielkich mocarstw w przeszłości i możliwej przyszłości ${ }^{7}$. W XIX w. pojawiło się też kilka prac geografów francuskich oraz niemieckich, wśród których na szczególną uwagę zasługują konstatacje Ernsta Kappa, który wprowadził do naukowego obiegu i zdefiniował pojęcie Lebensraum ${ }^{8}$ jako przestrzeń życiową niezbędną do funkcjonowania danej społeczności ${ }^{9}$. Z kolei Rudolf Kjellén (1864-1922), szwedzki teoretyk państwa, użył w 1899 r. po raz pierwszy terminu "geopolityka” i zdefiniował ją jako naukę o państwie jako organizmie przestrzennym. Podstawy wpływ na rozwój geopolityki w drugiej połowie XIX w. miała teoria Karola Darwina, a raczej swoista jej interpretacja polegająca na mechanicznym przenoszeniu praw dotyczących świata przyrody do świata społeczeństw ludzkich. Przedmiotem badań była zdolność państwa do przetrwania i rozwoju w walce o byt. Walka owa rozgrywała się w przestrzeni środowiska geograficznego, zwykle mniej lub bardziej nieprzyjaznego, co determinowało możliwości przetrwania. Za twórców geopolityki jako odrębnej dziedziny wiedzy uznaje się: Amerykanina Alfreda T. Mahana, Brytyjczyka Halforda J. Mackindera oraz Niemca Karla Haushofera.

Szczególne zasługi w zdefiniowaniu geopolityki przypisać należy angielskiemu geografowi, profesorowi z Oxfordu, typowemu przedstawicielowi brytyjskich elit schyłku epoki wiktoriańskiej, lecz jednocześnie uczonemu wizjonerowi, „Kiplingowi nauki brytyjskiej”. Mackinder zaprezentował przemyślany, geopolityczny model przestrzenny $\mathrm{Ziemi}^{10}$. W jego ujęciu na obraz

${ }^{7}$ L. von Ranke, Die Grossen Mächte, [b.m.w.] 1833.

${ }^{8}$ Lebensraum (niem.), przestrzeń życiowa. Pojęcie niejednoznaczne, na ogół przyjmowane było jako przestrzeń, w której dany naród rzeczywiście żyje, lecz także traktowane było postulatywnie, jako przestrzeń niezbędna do wyżywienia i rozwoju danego narodu. Służyło uzasadnieniu żądań Niemiec w czasie I wojny światowej, a po 1919 r., do krytyki traktatu wersalskiego, który jakoby miał pozbawić Niemcy przestrzeni życiowej (Volk ohne Raum - naród bez przestrzeni). W okresie nazistowskim termin traktowano biologicznie (darwinizm społeczny), jako obszar, w którym naród prowadzić może politykę autarkii gospodarczej i pomnażać swoją biologiczną substancję, co uzasadniało agresję i ekspansję Niemiec w czasie II wojny światowej.

${ }^{9}$ Za właściwego twórcę terminu Lebensraum uznać jednak należy Oskara Peschela, który posługiwał się nim w artykułach drukowanych w 1860 r. w czasopiśmie „Das Ausland”. Por.: F. Ratzel, Oskar Peschel, biogram zamieszczony w: Allgemeine Deutsche Biographie, Leipzig 1887.

${ }^{10}$ Halford Mackinder jest autorem kilkudziesięciu prac (artykuły i książki) z zakresu geopolityki i geostrategii. Pierwsza z nich: The Geographical Pivot of History, to tekst odczytu wygłoszonego w londyńskim Royal Geographical Society w 1904 r., a opublikowanego w „Geographical Journal" 1904, nr 6. Koncepcję swoją rozwijał przez kilkadziesiąt lat. Por.: H.J. Mackinder, Demokratic Ideals and Reality, wyd. i przedmowa A.J. Pearce, Westport Conn. 1962 (wznowienie Additional Papers 1981). 
globu składają się: Światowa Wyspa (World Island), czyli połączony kontynent Europy, Azji i Afryki, oraz otaczający ją Ocean, na którym rozrzucone są wyspy-satelity, Ameryka Północna, Południowa, Australia, Wielka Brytania, Japonia etc. Najważniejszą częścią Światowej Wyspy jest Heartland (Obszar Centralny, Serce Lądu; pierwotnie Pivot Area - Obszar Osiowy) ${ }^{11}$. Światowa Wyspa obejmuje większą część lądów i jest zamieszkiwana przez większość populacji ludzkiej, stąd wynika jej szczególna rola w historii. Czasoprzestrzenna teoria Mackindera łączy zatem geografię i historię ${ }^{12}$.

Jednak geopolityka jako nauka rozwinęła się po I wojnie światowej przede wszystkim w Niemczech, a czołowi przedstawiciele doktryny skupiali się wokół czasopism „Zeitschrift für Geopolitik” (1924-1944) oraz "Archiv für Bevölkerungswissenschaft und Bevölkerungspolitik" (od 1937 r.) ${ }^{13}$. Szczególną rolę odegrała w okresie nazistowskim, tworząc podstawy ideowe do ekspansji terytorialnej i związanej z nią polityki eksterminacji na skalę masową. Czołowym przedstawicielem geopolityki niemieckiej był wspomniany Karl Haushofer. Lecz koncepcje geopolityczne niemieckiego generała nie wychodziły zasadniczo poza myśl Mackindera. Był twórcą koncepcji geopolitycznej zakładającej podział świata na cztery panregiony geopolityczne rozciągające się południkowo: amerykański, niemiecki, rosyjski i japoński. Założyciel najsłynniejszego pisma geopolitycznego „Zeitschrift für Geopolitik”, zaangażowany politycznie w okresie III Rzeszy, był doradcą Adolfa Hitlera, także przez pewien czas Józefa Stalina, a w praktyce politycznej jego teorię próbowała realizować jedynie Japonia, odnosząc w latach trzydziestych XX w. znaczące sukcesy polityczne i militarne na tym polu ${ }^{14}$.

W niemieckiej praktyce politycznej, żywo nas interesującej, problem łączył się z pojęciami: Lebensraum (przestrzeń życiowa), Grossraum (wielka przestrzeń), Blut und Boden (krew i ziemia), Grossraumwirtschaft (gospodarka wielkiej przestrzeni) oraz Mitteleuropa (Europa Środkowa). Ta ostatnia koncepcja, głoszona przez ideologów i polityków niemieckich, miała bardzo istotne znaczenie, dotyczyła stworzenia zdominowanego przez Niemcy obszaru gospodarczego i geopolitycznego. Geopolityka to problem globalny, dotyczy każdego niemal państwa jako organizacji politycznej, której celem jest zapewnienie bezpieczeństwa swym obywatelom. W pewnym uproszczeniu możemy zdefiniować geopolitykę jako politykę prowadzoną w oparciu o realia po-

11 Termin Heartland został przez Mackindera zapożyczony od Jamesa Fairgrieve, autora książki Geografia i panowanie w świecie (1915). Geograficznie to centralna część Eurazji, najogólniej: od Oceanu Lodowatego na północy, góry północno-wschodniej Syberii i pustynie Mongolii na wschodzie oraz wielkie masywy górskie na południu (Hindukusz, Pamir, Karakorum, Wyżyna Tybetańska i masyw Himalajów). Jedyną otwartą i łatwo dostępną część Heartlandu stanowią rozległe obszary Niżu Europejskiego (Europa Wschodnia) - to właśnie owe „wrota Serca Lądu", czyli klucz do panowania nad światem.

${ }^{12}$ L. Moczulski, Geopolityka. Potęga w czasie i przestrzeni, Warszawa 2000, s. 7-14.

13 Por. chociażby: A. Wolff-Powęska, Doktryna geopolityki w Niemczech, Poznań 1979.

${ }^{14}$ L. Moczulski, dz. cyt., s. 18-19. 
łożenia geograficznego, a więc także środowiska geograficznego, klimatu etc. W takim zakresie dotyczy ona także Rzeczypospolitej, państwa restytuowanego w XX w. W przypadku Polski, położonej w sercu Europy, realia geopolityczne miały od wieków także bardzo istotny aspekt globalny, który stanowi część rozważań w prezentowanej pracy. Podstawą myślenia geopolitycznego był realizm polityczny, reprezentowany przez środowiska konserwatywne i narodowe. Do nurtu tego zaliczyć należy myśl polityczną ks. Adama Jerzego Czartoryskiego, Aleksandra Wielopolskiego oraz tradycję krakowskich stańczyków.

Powróćmy jednak do konstatacji Mackindera, gdyż jego teoria zawiera pewne istotne wskazania dotyczące spraw polskich. Nadrzędną troską brytyjskiego uczonego była trwałość Imperium, nad którym, co dostrzegało wielu, w XX w. „słońce już poczęło zachodzić”. Empirycznie fakt ten udowodniły wydarzenia I wojny światowej i wersalski pokój, które stały się początkiem łańcucha wydarzeń, zmierzających do dekompozycji globalnej brytyjskiej dominacji. Przez kilka wieków bowiem Wielka Brytania, dzięki położeniu geograficznemu, organizacji społecznej i potencjałowi ludzkiemu (Man-Power), stała się praktycznie dominującą $\mathrm{w}$ świecie siłą. Tymczasem wyrosły inne potęgi, opierające swoją siłę na niezmierzonych zasobach Wyspy Swiata. Mackinder zwrócił uwagę na to, iż potęga morska w dłuższej perspektywie czasowej zależy od podstawy lądowej. Geopolityczne prawo Mackindera sprowadzało się w skrócie i znaczącym uproszczeniu do stwierdzenia: kto panuje nad Wschodnią Europą, panuje nad Obszarem Centralnym; kto panuje nad Obszarem Centralnym, panuje nad Światową Wyspą; kto panuje nad Światową Wyspą, panuje nad światem. Wyspa Świata i Heartland stanowią zatem najważniejszy cel $\mathrm{w}$ grze o panowanie nad światem między potęgą morską i lądową. Kluczem do naturalnie ufortyfikowanego przez naturę Heartlandu jest otwarta przestrzeń między Morzami Bałtyckim i Czarnym, obszar Międzymorza, czyli Pas Środka - jak go nazwał Mackinder. Europa Środkowo-Wschodnia stanowi najistotniejszą część owego systemu.

Jedynym sposobem zdobycia trwałego panowania w świecie, „zwycięstwa w historii" - jak to określał - było przeszkodzenie w opanowaniu Heartlandu przez potęgę lądową. Cel ten można zrealizować, tworząc między Niemcami a Rosją system niezależnych i silnych państw Europy Środkowo-Wschodniej, którego najważniejszą częścią byłaby Polska. Zatem popieranie silnej Polski było podstawowym interesem brytyjskiej polityki i dyplomacji po I wojnie światowej. Tymczasem polityka Albionu w okresie międzywojennym, działając wbrew własnym najistotniejszym interesom, zrobiła wszystko dla zjednoczenia interesów Moskwy i Berlina - zamiast wzmocnić Pas Środka. Brytyjskie elity polityczne nie skorzystały z przemyślanych i przewidujących, ba - wizjonerskich koncepcji uczonego. Mackinder nie był słuchany, a jego myśli uważano za ekscentryczne. Zadecydował, jak często bywa, pragmatyzm. Praktyczni politycy parlamentarni myśleli w kategoriach kolejnych wyborów, a dłuższa niż pięcioletnia perspektywa czasowa graniczyła w ich 
mniemaniu z polityczną fantazją. Z koncepcji czasoprzestrzennej Mackindera skorzystali natomiast inni - Niemcy, Sowieci, Japończycy, następnie także Amerykanie. Ostatecznie, w wyniku II wojny światowej Pas Środka zawłaszczyli Sowieci, zamykając na wiele dziesięcioleci „wrota Heartlandu”"15.

Kluczem do dalszych rozważań jest „interes narodowy”, najważniejszy element systemu wartości nadrzędnych, niezbędny dla zaspokojenia potrzeb narodu. Pojęciem tym posługiwał się w swej publicystyce i działalności politycznej Roman Dmowski, ceniony współtwórca i orędownik polskiego nowoczesnego nacjonalizmu. Zawdzięczamy myśli Dmowskiego wiele. Zdefiniował i upowszechnił bowiem także istotę kolejnego ważnego pojęcia: „polityka polska”. Zerwał z ukształtowaną w XIX w. tradycją myślenia o Polsce w kategoriach romantycznych, walki dobra ze złem i ufnej wiary, że to pierwsze musi w końcu zwyciężyć. Zracjonalizował myślenie o narodzie i państwie. Romantyzm polityczny zastąpił politycznym realizmem. Przypomniał, iż w polityce liczy się nade wszystko interes i siła, niezwykle mało pozostawiając miejsca na romantyczne idee, emocje i uczucia. „Polityka polska" to pojęcie dla Dmowskiego kluczowe, bardziej adekwatnie oddające istotę sprawy niż "racja stanu”. „Politykę polską wiązał ściśle z bez wątpienia szerszym pojęciem »interesu narodowego «"16. To ważne przesłanie było efektem ewolucji pewnego szczególnego nurtu politycznego, nazwanego z czasem ogólnie i dość nieprecyzyjnie narodową demokracją, nurtu, który ukształtował u schyłku XIX w. pierwszą na ziemiach polskich nowoczesną partię polityczną.

Niezwykle interesująco swoje tezy prezentował Władysław Gizbert-Studnicki (1867-1953), mający opinię germanofila. Jego postrzeganie polskiej racji stanu zasługuje na uwagę.

Był politykiem o rzadko spotykanych w tym środowisku cechach charakteru, uczciwym, odważnym i bezkompromisowym. To stanowiło bez wątpienia $\mathrm{w}$ jego życiu zaletę, lecz bywało też przeszkodą. Postrzegano go bowiem niekiedy jako ekscentryka, a nawet dziwaka i zwalczano zaciekle, gdyż był inny, także dlatego, iż zbyt często mówił prawdę. Ponadto nie pełnił nigdy żadnych nobilitujących funkcji, które zwykle, w powierzchownych analizach, stanowiących jakże często jedynie odbicie vox populi, bywają miarą nadrzędną w ocenie każdej postaci publicznej. Brakowało jednak Studnickiemu pewnej cechy bardzo istotnej w działalności publicznej, określanej współcześnie nad-

${ }^{15}$ Nader interesujące uwagi na temat koncepcji geopolitycznych Mackindera znaleźć można w pracy Andrzeja Maśnicy, Świat kolisty i zwycięstwo w historii Sir Halforda Mackindera, „Stańczyk" 1995, nr 1(24), s. 24-38.

16 Por. uwagi Marka Kornata, Idee patriotyzmu w Polsce Odrodzonej (1918-1939), w: Polska czyli... Idee wspólnoty politycznej i tożsamości narodowej w polskiej tradycji intelektualnej, pod red. A. Rzegockiego, Kraków 2011, s. 128-130; także: M. Kułakowski (właśc. Józef Zieliński), Roman Dmowski w świetle listów i wspomnień, Londyn 1968, t. 1, s. 237 (list do Zygmunta Miłkowskiego z 13 września 1901 r.). 
używanym mianem charyzmy, czyli osobowości, którą można narzucić otoczeniu. Nie przyciągał uwagi głosem, gestem, wyglądem. Niewiele liczono się więc z jego zdaniem i nader często lekceważono głoszone przez niego poglądy. Jednakże w ocenie pozostającego pod wpływem jego myśli Stanisława Mackiewicza (Cata), Studnicki „przerabiał na program polityki realnej zew Wyspiańskiego z »Wesela«"17. To bardzo lapidarna, lecz ważna charakterystyka, bodaj najpełniej oddająca istotę jego działalności publicznej. Niewielu dorównywało mu pod tym względem.

Obawa przed realizacją Paktu Czterech (podpisanego ostatecznie 15 lipca 1933 r.) była bez wątpienia czynnikiem dominującym i determinującym poczynania polskiej dyplomacji na arenie międzynarodowej. Jednakże fiasko poniósł przypisywany Piłsudskiemu projekt wspólnej z Francją wojny prewencyjnej przeciwko Niemcom (marzec 1933 r.). Podobnie po zajęciu przez Niemcy 7 marca 1936 r. zdemilitaryzowanej strefy Nadrenii rozsądne działanie Becka, proponującego zbrojną akcję wraz z Francją i Wielką Brytanią przeciwko Niemcom, spotkało się z odmową. Wydarzenia powyższe powinny być definitywnym ostrzeżeniem dla polskiego rządu, iż koalicja z Zachodem przeciwko Niemcom prowadzi donikąd, jest politycznym samobójstwem, gdyż skłoni jedynie Niemcy do poszukania innego partnera - antypolskiego Związku Sowieckiego. Polska dyplomacja nie wyciągnęła jednak właściwych wniosków z szybko następujących po sobie wydarzeń ${ }^{18}$.

Po podpisaniu polsko-niemieckiej deklaracji o nieagresji (26 stycznia 1934 r.) niemiecka propagandowa wrzawa wokół "korytarza” znacząco ucichła na kilka lat. To było bez wątpienia bardzo dobrą stroną trafnej politycznie decyzji, którą podjął jeszcze Piłsudski. Pakt oznaczał bowiem odwrócenie kolejności niemieckich rewindykacji. Za czasów Republiki Weimarskiej był to "polski korytarz", a w czasie rządów nazistowskich postulowano najpierw inkorporację Austrii i Sudetów, a dopiero w dalszej kolejności artykułowano inne roszczenia terytorialne. Przy założeniu dobrej woli obu stron, lub inaczej mówiąc - zaistnieniu wspólnoty interesów - problem "korytarza” mógł zostać rozwiązany. Świadczy o tym przebieg późniejszych wydarzeń. Kwestia stała się ponownie aktualna dopiero w latach 1938-1939. Po raz pierwszy formalne żądanie budowy eksterytorialnej autostrady i linii kolejowej wysunęli Niemcy dopiero 24 października 1938 r. (minister spraw zagranicznych Joachim von Ribbentrop), nawiązując jedynie tym samym do wcześniejszych polskich propozycji. Zatem $\mathrm{w}$ tym zakresie niemieckie oczekiwania były dość umiarkowane, gdyż Hitlerowi bardzo zależało na ułożeniu modus vivendi z Polską. Ostatecznie projekt przybrał postać ponurej tragifarsy. Włoski

17 S. Mackiewicz (Cat), Historia Polski od 11 listopada 1918 r. do 17 września 1939 r., Warszawa 1989, s. 45.

18 G. Łukomski, Problem ",korytarza" w stosunkach polsko-niemieckich i na arenie międzynarodowej 1919-1939. Studium polityczne, Warszawa 2000, s. 146-147; M.K. Kamiński, M.J. Zachariasz, Polityka zagraniczna Rzeczypospolitej Polskiej 1918-1939, Warszawa 1998, s. 186-187. 
minister spraw zagranicznych Galeazzo Ciano, zabiegając o pogodzenie obu stron, radził ambasadorowi Rzeczypospolitej w Rzymie (gen. Bolesławowi Wieniawie-Długoszowskiemu) 15 maja 1939 r., by Polacy kazali Niemcom budować tunel pod kilkunastokilometrowym odcinkiem Pomorza ${ }^{19}$. W swojej publicystyce Studnicki, nie umniejszając rangi zagadnienia, podkreślał propagandowy wymiar "korytarzowego" problemu, który mógł zostać rozwiązany z korzyścią dla obu stron. Ostatecznie jednak do rozmów nie doszło - to właśnie „korytarz” i Gdańsk stały się propagandowym pretekstem do agresji niemieckiej na Polskę. II wojna światowa stała się faktem.

Postulaty Studnickiego w zakresie polskiej polityki zagranicznej nie zostały zrealizowane, ba, nie tylko nigdy nie były przez władze Rzeczypospolitej rozważane, lecz ich autora spotkały szykany administracyjne. Jednak z perspektywy polskiej racji stanu były bardzo rozsądną alternatywą, wyjściem o wiele lepszym, wartym co najmniej szczegółowych rozmów, niż kierunek konfrontacji militarnej z Niemcami. Co by się zatem stało, gdyby u schyłku lat trzydziestych przyjęto koncepcję Studnickiego, zakładającą sojusz z Niemcami, a w konsekwencji wspólną z nimi wojnę przeciw Sowietom? Zacznijmy od stwierdzenia faktu, iż Józef Beck zdecydowanie nie doceniał zagrożenia płynącego ze strony sowieckiej, równocześnie przeceniał rolę Polski jako partnera czy też kontrahenta państw zachodnich. Wcześniej dostrzegał je natomiast Piłsudski, który tuż przed śmiercią, jeszcze w 1934 r., przestrzegał swoich współpracowników, iż Związek Sowiecki stanowi dla Polski większe zagrożenie, niż Niemcy, chociaż $w$ bliskiej perspektywie prawdopodobieństwo zbrojnej agresji było większe ze strony Niemiec. Twierdził zasadnie, iż przeciwko Niemcom Polska mogła zawsze uzyskać - mimo trudności - jakąś pomoc z Zachodu, natomiast żadnej pomocy przeciwko Sowietom. Dowodziły tego kilkunastoletnie doświadczenia związane z polityką Zachodu wobec Moskwy, państwa nieprzewidywalnego politycznie, wstrząsanego ideologicznym eksperymentem, trochę enigmatycznego i egzotycznego, znajdującego się na marginesie światowej polityki od początku swego istnienia. Beck, chociaż uważał się za ucznia Marszałka i jednego z najbliższych współpracowników, nie wysłuchał zbyt uważnie wszystkich jego lekcji. Swoją mało elastyczną polityką doprowadził do sytuacji otwartego, przynoszącego wojnę konfliktu z zachodnim sąsiadem, zamiast szukać z Niemcami jakiegoś trwalszego modus vivendi. Przyznać jednak trzeba, iż miał wiele uzasadnionych przesłanek, gdy w latach 1938-1939 odrzucał kolejne propozycje przywódcy III Rzeszy. Przyjęcie dyktatu ze strony silniejszego sąsiada w dłuższej perspektywie czasowej równało się wasalizacji Rzeczypospolitej i przynajmniej częściowej utracie podmiotowości politycznej.

W tle owej gry wyłaniał się cień wschodniego sąsiada Rzeczypospolitej. Sowieci bowiem nigdy nie zaniechali, porzuconych jedynie czasowo z powo-

19 Tamże, s. 255-256; ponadto: S. Swianiewicz, W cieniu Katynia, Warszawa 1990, s. 15-16. 
du braku powodzenia w latach 1919-1923, planów rozszerzenia wpływów komunistycznych w Europie. Zdawano sobie sprawę z tego, iż kluczem do sukcesu było opanowanie Niemiec. Geneza i przebieg II wojny światowej w sposób empiryczny potwierdziły globalną grę sowieckich przywódców i międzynarodówki komunistycznej. Do rozstrzygnięć wojennych dążyły nie tylko Niemcy. W 1939 r. także Związek Sowiecki zmierzał do rozpętania wojny, a komunistyczni przywódcy tego państwa nie zawahali się przed porozumieniem z nazistami. Sowiecka gra rozpoczęła się już 10 marca $1939 \mathrm{r}$. Wygłoszona tego dnia mowa Stalina ,została dobrze zrozumiana w Berlinie”, a ostateczna w tej sprawie decyzja zapadła 19 sierpnia 1939 r. na posiedzeniu Biura Politycznego w Moskwie. Stalin postanowił zachęcić Hitlera do agresji zbrojnej w celu osiągnięcia własnych celów politycznych, tzn. do wznowienia ekspansji na Europę, zatrzymanej w 1920 r. w wyniku przegranej wojny z Polską. O pierwszych umizgach sowiecko-niemieckich dowiedział się ppłk dypl. Antoni Szymański, polski attaché wojskowy w Berlinie, wybitny znawca stosunków niemieckich.

2 maja 1939 r., gdy stosunki polsko-niemieckie były już bardzo napięte, a droga do ich normalizacji niemal wykluczona, Szymański niespodziewanie zaproszony został na przyjęcie urodzinowe do Hansa H. Lammersa ${ }^{20}$, szefa gabinetu cywilnego Hitlera (Kancelaria Rzeszy). Przy stole siedział obok gen. Karla Bodenschatza ${ }^{21}$. Późnym wieczorem, gdy miało się ono ku końcowi, Niemiec poprosił Szymańskiego o krótką rozmowę na osobności. Polski attachè właściwie zrozumiał intencje niemieckiego partnera, iż chodzi o rzecz niezwykłej wagi. Warto ponadto zwrócić uwagę na fakt, iż było to w kilka dni po słynnym, agresywnym wystąpieniu Hitlera w Reichstagu - 28 kwietnia tego roku - i w kilka tygodni po stanowiącym coraz wyraźniejszy fakt polityczno-wojskowy porozumieniu polsko-brytyjskim. „[...] Zwracam się do pana z prośbą - mówił Bodenschatz - o szczególnie uważne wysłuchanie mej wiadomości. Proszę pana, jeżeli Hitler dojdzie do przekonania, że Niemcy mogą być od wschodu okrążone przez Polskę, to nie zawaha się połączyć nawet z samym... diabłem! A nie ma chyba między nami wątpliwości kim jest

${ }^{20}$ Hans Heinrich Lammers, ur. 1897, w latach 1933-1945 szef Kancelarii Rzeszy.

${ }^{21}$ Polski attachè bardzo zwięźle scharakteryzował osobowość generała, zaufanego Hermanna Göringa: „Skłonny jestem - wspominał - generała Bodenschatza zaliczać do intelektualnie mniej rzutkich [sic! - G.Ł.]. Występowała u niego natomiast pewność siebie i chęć imponowania wiadomościami i zapowiedziami, które w dalszym biegu wydarzeń sprawdzały się [...]". Bodenschatz był już w czasie I wojny światowej (1917-1918) adiutantem ówczesnego kpt. Hermanna Gőringa, dowódcy eskadry im. Manfreda von Richthofena, po śmierci lotniczej tegoż. Stąd wynikały bliskie stosunki służbowe i osobiste obu oficerów. Bodenschatz był np. jedynym niemieckim oficerem, który brał udział w większości posiedzeń gabinetu Rzeszy, nie pełniąc żadnej znaczącej funkcji oficjalnej. Był więc osobą bardzo dobrze zorientowaną w wielu najbardziej tajnych planach niemieckiej polityki. G. Łukomski, Generał brygady Antoni Szymański (1894-1973). Wielkopolanin - żotnierz i dyplomata, Pruszków-Warszawa-Londyn 2006, s. 37-39, 78-80. 
»der Teufel« [...] Bodenschatz wypowiedział te trzy zdania głosem przyciszonym, niemal uroczystym [...]”. Myśl tę powtórzył kilkakrotnie. „Rewelacje” niemieckiego oficera były zapewne dyskretną próbą niemieckich kół decyzyjnych wywarcia presji politycznej na polskiego partnera lub też posługiwał się nim Göring w swej akcji „zapobieżenia wojnie”"22.

Było dla Szymańskiego oczywiste, iż chodziło o krystalizujące się porozumienie niemiecko-sowieckie, Hitlera i Stalina. Opierając się na dotychczasowym doświadczeniu, w pełni docenił wagę sygnału otrzymanego od niemieckiego rozmówcy. Jeszcze tej samej nocy polski attaché wysłał depeszę szyfrową do swych przełożonych, informując o zasłyszanych rewelacjach. Dodał, iż poprzednie informacje z tego źródła (Bodenschatz), dotyczące zajęcia Nadrenii, Austrii, Sudetów itp., zawsze dotąd potwierdzały się w zupełności. Przełożeni zareagowali natychmiast. Attaché niezwłocznie wezwany został do Warszawy, gdzie przybył tego samego dnia wieczorem (w nocy z 3 na 4 maja), dosłownie w 24 godziny po rozmowie z Bodenschatzem, by zdać szczegółowe sprawozdanie z "ostrzeżenia" uzyskanego ze strony niemieckiego generała, którego działanie było z pewnością - jak się domyślał bardzo starannie przygotowaną akcją niemieckiego wywiadu. Szymański podaje, że marszałek Edward Rydz-Śmigły oraz gen. Stachiewicz „byli zupełnie zaskoczeni zapowiedzianą woltą hitlerowską", wyczuł ponadto pewien ich dystans wobec uzyskanych informacji, uzasadniony zapewne z punktu widzenia najwyższych władz wojskowych. Uważano je w Warszawie raczej za rodzaj swoistej niemieckiej gry dyplomatycznej i wywiadowczej, której celem było zdezorientowanie, a nawet zastraszenie przeciwnika. Niemniej jednak zwierzchnicy Szymańskiego z całą pewnością byli na bieżąco informowani o niemieckich przygotowaniach wojennych, a co najmniej od maja $1939 \mathrm{r}$. także o rysującej się nowej konfiguracji politycznej wynikającej z postępującego porozumienia niemiecko-sowieckiego. Taki alians był najbardziej dramatycznym scenariuszem, jaki mogli wyobrazić sobie wszyscy przywódcy odrodzonego państwa, poczynając od czasu zakończenia wojny polsko-bolszewickiej. Stawiał on bowiem pod znakiem zapytania dalszy niepodległy byt Rzeczypospolitej, podobnie jak bywało to niejednokrotnie w przeszłości. Przed takim scenariuszem przestrzegał m.in. Piłsudski, usiłujący znaleźć wyjście $\mathrm{z}$ fatalnej geopolitycznej konfiguracji ${ }^{23}$.

Porozumienie niemiecko-sowieckie z 23 sierpnia 1939 r. wyznaczyło nie tylko nowe granice i strefy wpływów między kontrahentami. Postanowiono

22 A. Szymański, Zły sąsiad. Niemcy 1932-1939 w oświetleniu polskiego attaché wojskowego $w$ Berlinie, Londyn 1959, s. 139-140.

${ }^{23}$ Na temat uwarunkowań politycznych i militarnych związanych z polskimi planami na wypadek wojny zob.: [Gen. dyw.] W. Stachiewicz, Pisma, t. 1, Przygotowania wojenne w Polsce 1935-1939, „Zeszyty Historyczne” (Paryż) 1977, s. 40, szczególnie s. 178-232; por. także uwagi Kazimierza Okulicza, Czy Beck naprawdę chciał dokonać zwrotu polityki polskiej w sierpniu 1939 roku?, „Zeszyty Historyczne” 1977, z. 42, s. 200-217. 
wesprzeć gospodarczo Niemcy, dostarczając im surowców przemysłowych i żywności. Jednocześnie kontynuowano prowadzoną od lat, zwłaszcza we Francji, propagandę komunistyczną przeciwko wysiłkowi wojennemu państw europejskich. W planach sowieckich powinna to być wojna długotrwała i - co istotne - prowadzona możliwie długo bez udziału Sowietów, którzy zyskają czas na wzmocnienie własnego potencjału zbrojnego. Mniej istotny był natomiast wynik zbrojnych zmagań państw europejskich. W przypadku zwycięstwa bowiem Niemcy będą wyczerpane, a więc niegroźne. Natomiast w przypadku wygranej państw zachodnich będzie można przyłączyć się do zwycięzców. W efekcie Sowieci w sposób naturalny osiągną dawno planowaną hegemonię na Starym Kontynencie ${ }^{24}$.

Czy zatem odrzucenie sojuszu z Niemcami i w konsekwencji wspólnej z nimi wojny przeciwko Sowietom było rzeczywiście lepszym dla Polski rozwiązaniem? Koalicja Polski z państwami zachodnimi w praktyce oznaczała, iż zdeterminowani w swych zamiarach Niemcy poszukali innego, nader chętnego do współdziałania partnera - było nim bardzo antypolsko nastawione państwo sowieckie, z gruntu negujące fakt istnienia niepodległego państwa polskiego i tolerujące fakt ten jedynie z konieczności - co w rezultacie stało się dla Polski politycznym samobójstwem. Nie tylko Beck popełnił fatalny w skutkach błąd, popełniła go niemal cała ówczesna polska elita polityczna, zarówno rząd, jak i większość opozycji. Nie umiano i nie chciano przekonać społeczeństwa zorientowanego nie tylko antyniemiecko (także z powodu rządowej propagandy tuż przed wojną), lecz przede wszystkim antysowiecko - do innego, bardziej pragmatycznego rozwiązania. Warto podkreślić, iż polska opinia publiczna była podzielona, znacząca część społeczeństwa nastawiona była antysowiecko, nurt ten występował nawet na kresach zachodnich, w Wielkopolsce, na Śląsku i Pomorzu, gdzie szczególnie dostrzegano bliskość i realność zagrożenia niemieckiego, a pamięć zaborów była jeszcze bardzo żywa. Zauważyć ponadto należy, że nigdy przedtem w dziejach najnowszych Niemcy nie były skłonne do tak daleko idącej współpracy z Polską, gdyż nigdy bardziej nie potrzebowały polskiej pomocy niż przed planowaną rozprawą z Sowietami. Ponadto przypomnieć należy, iż stereotyp Niemiec jako źródła i modelowego niemal przykładu wszelkiego zła, istniejący w ograniczonym zakresie od czasów Wielkiej Wojny, definitywnie utrwalony został dopiero po zakończeniu II wojny światowej przez propagandę aliancką, a zwłaszcza przez komunistyczną machinę propagandową. Wśród większości europejskich elit politycznych w okresie między wojnami dominujący był natomiast pogląd o realnym zagrożeniu komunistycznym (znamiennym wyjątkiem była opanowana przez lewicę Francja). Sowiety były zatem owym "diabłem" w o wiele większym stopniu niż Niemcy.

24 Por. także: P. Zaremba, Historia Dwudziestolecia (1918-1939), do druku przygotował M. Łatyński, Wrocław 1991, s. 487-497. 
W 1939 r. zabrakło szerokiej wizji politycznej, zamiast niej scenę zmagań zapełnił partykularyzm interesów, zamiast wielkości - nader często małość i małostkowość w zakresie podejmowanych działań. Nie słuchano głosów myślących inaczej i zepchnięto ich na margines życia publicznego. Tania propaganda, mówiąca o tym, że „nie oddamy nawet guzika”, zastąpiła sensowną akcję uświadamiającą społeczeństwo w zakresie możliwych rozwiązań, chociaż oczywiście nie było to łatwe i wymagało długich, żmudnych i wielokierunkowych działań ${ }^{25}$. Notabene, w swej wymowie propaganda owa bardzo przypominała ton rosyjskiej propagandy $\mathrm{w}$ przededniu I wojny światowej. Rządzący krajem, w większości legioniści z 1914 r., nie zawsze dorośli do zadań, które stawiał rok 1939. Niestety, pragmatycznie i rozsądnie myślących Studnickich - "germanofilów" - było niewielu, zbyt mało, by mogli wpłynąć na bieg wydarzeń.

Na postawione wyżej pytanie możemy zatem odpowiedzieć: tak, przyjęcie propozycji niemieckich było - także z perspektywy historycznej - lepszym dla Polski rozwiązaniem. Do takiej właśnie koncepcji wspólnej walki z Sowietami skłaniał się Studnicki. Jakie byłyby implikacje takiego rozwiązania? Geopolityczne położenie Polski determinowało ścisłą współpracę z którymś z sąsiadów, nawet kosztem utraty części terytorium - gdyż to, jak uczy doświadczenie, zawsze jest do odzyskania - niż szukanie egzotycznych sojuszy na Zachodzie. Ścisłe współdziałanie z Sowietami było wykluczone, gdyż w praktyce oznaczało finis Poloniae - utratę państwowości na zawsze ( $w$ przypadku relacji z Sowietami nie można było liczyć na odzyskanie czegokolwiek), Zachód nie pomógłby w odzyskaniu utraconej suwerenności w najmniejszym zakresie, gdyż nie leżało to w interesie państw Europy Zachodniej. Potwierdzały to bolesne doświadczenia dziewiętnastowiecznej walki o restytucję państwa. Tymczasem jakakolwiek forma uzależnienia od Niemiec w dłuższej perspektywie, innej, zmieniającej się globalnej konfiguracji politycznej, z pewnością mogła się zmienić. W wyniku wspólnej akcji zbrojnej państwo sowieckie z pewnością by nie przetrwało. Do takiej konstatacji skłania analiza wydarzeń wojny niemiecko-sowieckiej. W grudniu 1941 r. Niemcy, walcząc bez armii polskiej, a jedynie z aliantami, których armie, nawet łącznie, były o wiele słabszymi od Wehrmachtu i sprawiającymi Niemcom często więcej kłopotów niż pożytku, byli o krok od zdobycia Moskwy, co w praktyce oznaczałoby rozpad scentralizowanego imperium sowieckiego. Jednakże utrzymanie i efektywne wykorzystanie tak wielkiego obszaru, zwłaszcza wobec fanatycznego stosowania drakońskich metod okupacyjnych (terror i eksterminacja całych narodów) - na dłuższą metę byłoby niemożliwe. Przypomnijmy ponadto, że wojna niemiecko-sowiecka, o czym mówi się bardzo niechętnie, stała się ogólnoeuropejską krucjatą antykomunistyczną. Uczestniczyli w niej bowiem nie tylko sojusznicy Niemiec, lecz i for-

25 G. Łukomski. Propaganda polska 1939-1940, w: Na obrzeżach polityki, cz. 8, pod red. M. Kosmana, Poznań 2010, s. 119-132. 
macje zbrojne z krajów okupowanych, ochotniczo, w większości bez specjalnej presji ze strony niemieckiej. Brakowało jedynie oddziałów polskich (sic!).

W skali globalnej jednak oraz w dłuższej perspektywie czasowej Niemcy z pewnością przegrałyby wojnę z Zachodem, z wielu powodów, przede wszystkim z powodu różnicy potencjałów, zasobów surowcowych, demograficznych etc. Jednakże bardzo istotnym rezultatem kilkuletnich zmagań wojennych stałoby się rozbicie Związku Sowieckiego. Na jego miejscu powstałby zapewne szereg państw narodowych - części składowych byłego imperium. A jaka przyszłość czekałaby wówczas aliantów Niemiec? Przykłady powojennych losów Węgier, Rumunii, Finlandii, nade wszystko Włoch, Japonii itd. uczą, iż los Polski nie byłby gorszy. Natomiast zyski z pewnością znaczące. Państwo nie poniosłoby tak olbrzymich strat demograficznych, terytorialnych i materialnych, jak to się stało, gdy byliśmy sojusznikiem koalicji antyniemieckiej - a bilans strat był istotnie przerażający i odczuwalny przez dziesięciolecia. Wielce symptomatyczny i pouczający jest też przykład Francji, pozostającej przecież od wieków, głównie na tle sporów terytorialnych, w trudnych relacjach z niemieckimi sąsiadami.

Relatywnie zatem Polska poniosła największe straty i ofiary w czasie wojny i niejako "w nagrodę" odebrano jej połowę terytorium i "podarowano" Sowietom. W zamian dostaliśmy tzw. rekompensatę w postaci kresów zachodnich. W swej istocie natomiast było to jedynie oddanie własności utraconej w przeszłości przez Polskę na rzecz państw niemieckich. Posługując się propagandową retoryką marksistowską, była to jedynie „,sprawiedliwość dziejowa". Sowieci stworzyli kolaboracyjny marionetkowy rząd komunistyczny w Polsce, a kolejne lata przyniosły, wbrew woli większości narodu, umocnienie się komunistów w Polsce. W rezultacie nie zyskaliśmy nic, prócz regresu cywilizacyjnego i kulturowego, związanego nieodmiennie z komunistycznym systemem totalitarnym. Jak by tego było mało, twórcy kolaboranckich rządów w latach 1944-1989 uchodzili w ówczesnej publicystyce i historiografii za bohaterów narodowych. Kolaborację z Sowietami prezentowano jako zaletę i jedynie słuszny wybór "dziejowy”, słowem powód do dumy, współpracę zaś z Niemcami zawsze potępiano jako zbrodniczą. Podsumowując ten wątek, powtórzmy zatem, że z pewnością lepiej było znaleźć się po drugiej stronie barykady; ofiary i straty byłyby dużo mniejsze, a przede wszystkim historycznie uzasadnione, gdyż zdecydowanie bardziej zgodne z polską racją stanu' ${ }^{26}$.

Współczesne realia geopolityczne, przynależność obu krajów, Polski i Niemiec, do Unii Europejskiej kreują postawy współpracy i pojednania, wspólnego budowania relacji opartych na zaufaniu. Przyświeca owym działaniom, podobnie jak niegdyś poprzednikom, troska o przyszłe pokolenia młodych Polaków i Niemców.

${ }^{26}$ Por. na ten temat także nader interesujące konstatacje: J. Łojek [Leopold Jeżewski], Agresja 17 września 1939. Studium aspektów politycznych, Warszawa 1990, s. 10-18. Problem przekracza ramy niniejszej pracy i z pewnością wymaga rozwinięcia. 
Grzegorz Łukomski

\author{
Polacy i Niemcy \\ w geopolitycznej przestrzeni $X X$ w.
}

\begin{abstract}
Streszczenie
Wielowiekowe trudne sąsiedztwo polsko-niemieckie skłania do refleksji nad wzajemną akulturacją, mającą swoje pozytywne i negatywne skutki, splataniem się w naszych dziejach wielkiej polityki i mikrohistorii, ludzkich losów wpisanych w dzieje obu narodów. W przeszłości relacje polsko - niemieckie kreowali nade wszystko intelektualiści i politycy, oni narzucali je społeczeństwom. W niemieckiej praktyce politycznej zagadnienie geopolityki łączyło się z pojęciami: Lebensraum (przestrzeń życiowa), Grossraum (wielka przestrzeń), Blut und Boden (krew i ziemia), Grossraumwirtschaft (gospodarka wielkiej przestrzeni) oraz Mitteleuropa (Europa Środkowa). Ta ostatnia koncepcja, głoszona przez ideologów i polityków niemieckich, miała bardzo istotne znaczenie, dotyczyła stworzenia zdominowanego przez Niemcy obszaru gospodarczego i geopolitycznego. Geopolityka to problem globalny, dotyczy każdego niemal państwa jako organizacji politycznej, której celem jest zapewnienie bezpieczeństwa swym obywatelom. W przypadku Polski, położonej w sercu Europy, realia geopolityczne miały od wieków także bardzo istotny aspekt globalny, który stanowi część rozważań w prezentowanej pracy. Podstawą myślenia geopolitycznego był realizm polityczny, reprezentowany przez środowiska konserwatywne i narodowe. Do nurtu tego zaliczyć należy myśl polityczną ks. Adama Jerzego Czartoryskiego, Aleksandra Wielopolskiego, oraz tradycję krakowskich stańczyków.
\end{abstract}

\title{
Poles and Germans in Geopolitical Reality in the $20^{\text {th }}$ Century
}

\begin{abstract}
Long, difficult Polish-German neighborhood is an inspiration to reflect upon the mutual acculturation, which has both positive and negative outcomes, and to reflect on how the great politics and micro-history overlapped across our history. It is also aimed to consider individual histories inscribed in the history of both nations. In the past, Polish-German relations were primarily created by politicians and great intellectual minds. They imposed those relations onto society. In the German politics, the notion of geopolitics was related to the notions of Lebensraum (living space), Grossraum (the great space), Blut und Boden (blood and soil), Grossraumwirtschaft (the economy of the great space) and Mitteleuropa (Central Europe). The last one, advocated by some German ideologists and politicians, was of primary significance. It was about creating a German-dominated economic and geopolitical area. Geopolitics is a global issue, it concerns almost every state - a political organization - which aims to provide security for its own citizens. In the case of Poland, a country located in the heart of Europe, for centuries, geopolitical reality has had an important global aspect, which is part of the discussion in the article. Political realism was the foundation of geopolitical thought, and it was represented by the conservative and national circles, e. g. political thought of father Adam Jerzy Czartoryski and Aleksander Wielkopolski and the tradition of Stanczyks from Cracow.
\end{abstract}

